\title{
Attributes of social capital in the educational organisation
}

Mirela Minică 


\title{
Attributes of social capital in the educational organisation
}

\author{
Mirela Minică ${ }^{\mathrm{a}^{*}}$ \\ ${ }^{a}$ Babes-Bolyai University, Faculty of Economics and Business Administration, \\ Teodor Mihail Street, no.58-60, Cluj-Napoca, 400591, Romania \\ *Corresponding author: mirela.minica@econ.ubbcluj.ro
}

\section{Abstract}

\section{Keywords:}

school organisation; social capital; management of change; reform.
The article highlights according to the concept of social capital, the changes generated by the COVID-19 pandemic in the educational system.

This research identified the attributes of social capital at the level of the adults involved in the educational process (parents, students), the impact of the current period on them and the opinion of the respondents regarding the education reform.

The conclusions of the study prove an activation of the intentions of involvement and participation in the management structures and in the educational projects at the level of the school organization, along with a low degree of confidence in the way the reform of the educational system is designed and implemented. Change management in recent years has highlighted the need for school involvement in the development of social capital and also the need to increase the role of social stakeholders in solving the challenges facing school organizations.

\section{Zusammenfasung}

\section{Schlüsselworte:}

Schulorganisation; Sozialkapital;

Änderungsmanagement;

Reform.
Der Artikel beleuchtet aus der Perspektive des Konzepts des Sozialkapitals die Veränderungen, die im Bildungssystem durch die COVID-19-Pandemie hervorgerufen wurden.

Durch die Untersuchung wurden die Eigenschaften des Sozialkapitals auf der Ebene der am Bildungsprozess beteiligten Erwachsenen (Eltern, Schüler), die Auswirkungen der aktuellen Periode auf sie und die Meinung der Befragten zur Bildungsreform identifiziert.

Die Schlussfolgerungen der Studie belegen eine Aktivierung der Beteiligungs- und Beteiligungsabsichten in den Führungsstrukturen und in den Bildungsprojekten auf Ebene der Schulorganisation bei gleichzeitig geringem Vertrauen in die Reform des Bildungssystems konzipiert und umgesetzt. Das Veränderungsmanagement der letzten Jahre hat die Notwendigkeit der Einbeziehung der Schulen in die Entwicklung des Sozialkapitals hervorgehoben, aber auch die Notwendigkeit, die Rolle der sozialen Akteure bei der Lösung der Herausforderungen, mit denen Schulorganisationen konfrontiert sind, zu stärken.

\section{Introduction}

The definition of the concept of social capital is not yet unanimously recognised by researchers in the field, but its role in the development of a region or country is highlighted in many an empirical studies.

Systemic analysis allows us to understand the interdependent relationship between school and the social system. The specialised literature referring to the way in which the transformations in the social system trigger changes in the education system, put forward discussion in the context of cause-effect determinism, the principle of correspondence.

The school / educational organisation, by its very characteristics and attributions, represents an open social system, in permanent contact with the external environment, and that is why the degree of the social capital development generates a greater or lesser adaptability to change.

The educational relevance of this paper starts from one of the psychological characteristics of the school organisation, namely the assignment of the learning organisation syntagm, from the perspective of its influence both on the microenvironment and on the community and society as a whole, and thus the analysis of the attitude towards changes generated by the COVID-19 pandemic in the educational process are a highly relevant issue.

\section{Conceptual approaches}

E. Păun (1999) defines the organization as "a system of activities structured around explicitly formulated purposes (goals, objectives), which involve a large number of individuals who have well-defined 
statutes and roles within a differentiated structure, with functions of management and activity coordination".

From this definition, the main characteristics of an organization can be deduced:

- goals stated clearly: it is important that the goals of the organisation are as convergent as possible with individual goals so as not to lead to frustrations;

- high number of individuals interacting with one another: however, this does not mean that the strength of an organisation is directly proportional to the number of individuals constituting it; the success of an organisation depends on the quality of interactions between its composing individuals;

- socially regulated division of labour: individuals fill different positions and play distinct roles, so they have a certain status; the organised activity supposes an internal structure where there are well determined positions and the information circulates both horizontally and vertically;

- management through its functions unites, in an integrated manner, the individuals constituting the organisation, its goals and its functionally differentiated activities.

In consideration of the above, the defining factors for an organisation have the following characteristics: organisational structure, organisational behaviour and organisational change materialised in staff development.

Before analysing the analogies between the social system and the school, it is necessary to emphasize the characteristics of the school as an open system. (E. Păun, 1999)

1. Globalism-school as open system is in its turn part of this system (the social system);

2. Teleonomy - the school is focused on certain goals, as a system it tends to reach a functional balance. The school system can be considered a system under formation, evolving towards a higher degree of unity and also towards a high degree of constitution (completion) or balance. The following situations may occur:

- the state of higher equilibrium in which the school resists restructurings and faces unfavourable factors from the external environment;

- the state of dynamic balance, which is an indication of stability and development. Dynamic equilibrium means that the system is capable of growth and change without restructuring itself;

- the state of stagnation, encountered when a system is no longer able to adjust, to self-adapt. But it cannot remain in this state for too long because the state of decline inevitably follows;

- the state of decline and disintegration, when the system moves away from the completion stage, becoming confused. This state is found in systems that are too large (too many constituent elements) or too small (not enough agents in relation to the assumed objectives).

3. Equifinality - school succeeds in achieving its projects and objectives by different means;

4. Entropy - it expresses the degree of disorganisation that increases in closed systems. School is an open system, so entropy is not found among its features. Negentropy represents information, so when negentropy is introduced into a system through different channels, entropy decreases. Disorders in the system can also have positive meanings because they lead to resettlement and readjustment. Although in certain systems the input of information from the outside can have beneficial influences in the reorganising of the respective systems, in the educational system the import of social dysfunctions (either economic or political) most often disorganises it.

Within the education reform, school was subjected to multiple influences and handled in the process. The changes inside the school were not the desired ones precisely due to the imbalance of the internal processes.

5. Feedback reflects the property of the results obtained to influence the subsequent behaviour of the system. The feedback can be positive for amplifying or maintaining the operation of the system and negative for the role of regulator, correction, braking. The self-regulation of the system depends on the flow of information and the quality of communication between the different subcomponents.

\section{Literature review}

A clarification of concepts such as social capital and human capital is required in line with the microlevel approach of the educational organization.

In the literature, there is a growing consensus on the approach of social capital as a multidimensional 
construction. Social capital contains different dimensions and more indicators are needed for these dimensions to be properly measured (e.g., Johnston and Percy Smith, 2003) - indicators that may not necessarily correlate very closely with each other (Woolcock, 1998).

Until Bourdieu (1981, 1985) and Coleman (1988, 1990) constructed their individual theories of social capital, the social mechanism underlying this phenomenon was unclear (Portes, 1998; Flap, 1999).

They argue that social capital has not only a private aspect - reaching the personal goal - but also a public side. Social capital can have positive benefits for the wider society in which it manifests. Therefore, social capital can be aggregated, which means that it can be treated not only as a characteristic of individuals and their relationships, but also as a property of countries and regions.

The higher the levels of these characteristics, the more action and cooperation for mutual benefits and collective goods is facilitated.

Both Putnam (2000) and Fukuyama (1995) argue that countries or regions exhibiting higher levels of social capital aggregation are therefore linked to higher levels of political and economic performance. Others, such as Paxton (2002), have generalized the individual and socially aggregated level of the capital approach. They argue that social capital can be analysed on several levels, namely on the micro level of individuals and small groups, on the meso level of communities and associations, and on the macro level of sub-supranational regions and nation states.

Macro-sociological theories see social capital as the cement of society that makes it possible for people to cooperate in the common interest. Collective action requires widespread reciprocity, trust and "soft" regulations that go beyond the logic of simple instrumental reciprocity.

Putnam (2000) refers to the positive consequences of social capital - mutual support, cooperation, trust, institutional effectiveness - and negative manifestations - sectarianism, ethnocentrism, corruption.

From the perspective of the educational organisation, the attributes of social capital are manifested in the relationship between school / university and their adult beneficiaries, who can be directly involved in implementing educational projects, volunteering activities becoming active participants in a participatory management system of these institutions.

Many researchers (Clifton \& Roberts, 1993; Evans-Harvey, 1995; Teachman, Paasch \& Carver, 1997) consider the educational environment to be exciting and supportive for students, facilitating the acquisition of skills to a greater or lesser extent.

The social capital theory provides an eloquent framework for demonstrating how parents and students relate to their own expectations and can engage in the development of skills and attitudes that contribute to amplifying the positive values of human capital (Etcheverry, Clifton \& Roberts, 2001).

A series of qualities from economic management, sociology, political science, psychosocial are transferred to educational management (Cristea, 1998):

- economic management provides the model for capitalizing on the institution's resources;

- psychological management offers the quality of directing interests;

- psychosocial management orients the personality resources both internally and relationally.

According to the experiential approach of a social / educational process (Trișcă, 2013), the dimensions of experience include the conceptual categories based on which the client phenomenologically evaluates the lived experience, more precisely: the pragmatic dimension of the experience (referring to the sacrifices / benefits perceived by the client in relation with the lived experience), the peace of mind dimension (related to aspects such as property and personal safety), the relational dimension (the relationship with other people, the relationship with the ideal self, the means of asserting social identity, group membership), the empowerment dimension (recognizing the importance of empowered interactions that underlie the co-creation of value), the escaping dimension, the fun dimension, the educational dimension, the surprise dimension, the aesthetic dimension of the experience, the nostalgic remembrance dimension (memory, sharing personal experiences with other people). We can say that the relational dimension is extremely important in the educational process, its absence in the current pandemic situation causing an incomplete and inefficient learning experience. 


\section{4. Identifying the attributes of the social capital}

Educational organisations in Romania do not yet have an efficient and viable system of communication between their main members (pupils / students, teachers, parents, local administration).

In the management of schools / universities, the magistocentric current was predominant, which emphasized the role of the teacher in the transmission of knowledge and the use of expository methods to the detriment of heuristic strategies.

The research question to be answered in this study is the following: Have the changes in the educational process caused by the COVID-19 pandemic triggered the improvement of the positive aspects of social capital (involvement, cooperation, trust, effectiveness)?

\section{The research objectives are as follows:}

Identifying the perception and attitude the main direct and indirect adult beneficiaries towards education;

Determining the level of social capital attributes under pandemic conditions;

Establishing an opinion regarding on education reform.

Research hypothesis statement: Pandemic increased the intention of involvement / cooperation among parents and students.

\section{Research methodology}

The design of the research generated an experimental, cross-sectional, multifactorial research, based on a Google Forms online questionnaire applied between March and April 2020, a period in which we passed from classroom teaching to generalised online teaching.

The sample of content generated by the topic of the questions contained in the questionnaire addresses the following aspects: the importance and perception of the purpose of education; changes in the educational process (online teaching); attributes of social capital (degree of involvement of parents / students in learning and assessment, volunteering, educational projects, management structures); degree of trust in the education reform (system improvement, financing, depolitisation, adaptation to labour market requirements).
The sample of participants was randomly constituted of 201 people distributed according to the following criteria:

Biologic gender: 162 women and 39 men;

Age: 49 pers. (18-25 years of age); 36 pers. (26-35 years); 80 pers. (aged 36-45) and 36 pers. (over 46);

Marital status: married / in a couple: 138 pers.; single: 63 pers.;

Employed: 138 pers. (in the country); 4 pers. (abroad); 59 pers. (unemployed);

The level of monthly family income: 46 pers. (below 2500 lei); 89 pers. (2501-5000 lei); 34 pers. (between 5001 and 7500 lei); 32 pers. (over 7501 lei);

Capacity of the adult respondent: 132 pers. parents/legal guardians; 69 pers. students;

The level of education of children / young people: 50 pers. (preschool); 37 pers. (elementary school); 38 pers. (middle school); 48 pers. (high school); 66 pers. (university).

The indirect survey method was used (online) which included 28 closed questions, of which 6 factual questions and 22 opinion questions, using the SPSS program for analysis and interpretation of the information obtained. Responses were graded on a Lickert 5-level scale (disagreement, slight disagreement, neither agreement nor disagreement, slight agreement and agreement).

\section{Research results}

The first four questions in the questionnaire aimed to identify the perception of education.

All respondents agreed on the importance of education, but in terms of how education is valued in Romanian society, only $39.1 \%$ considered it to be properly perceived.

As the perception of the purpose of education is concerned $83.7 \%$ of the subjects consider that this should be the development of professional skills for pupils and students.

$99.1 \%$ of those surveyed place the following values on the list of values to be developed through education: work, honesty, respect and cooperation. These answers obviously highlight the exact awareness of the attributes that, unfortunately, are deficient in contemporary Romanian society. 
The second set of questions aimed to identify the attitude towards the educational process, with the particularities determined by the current pandemic.

When asked about the effectiveness of online teaching, the percentage of those who consider it inappropriate is $49.5 \%, 15.3 \%$ are in the neutral zone, only $35.5 \%$ considering it appropriate. From the inferential analysis of the correlation coefficients with the distribution of adult parents / students, we found that the level of significance (Sig.) is below the value of 0.05 for the student category, highlighting the fact that this category is more satisfied with this teaching system. This attitude is determined on the one hand by the faster adaptative reaction of the university environment to change, by the increased digital skills of teachers and students, but also by the profile of the responding students, determined by their occupational status ( $28.5 \%$ of them being employed).

The statement "Only teachers are involved in the teaching-learning-assessment process (even during the pandemic period)" generated the disagreement of $25.3 \%$ of the respondents and $8.4 \%$ expressed a neutral attitude. Interestingly, the Sig. is less than 0.05 , and the Pearson correlation coefficient has a value of 0.7 indicating a strong link between parent status for pre-schoolers and high school children, but a lower value of 0.4 for parents of primary school children. Could these correlations be an indication of the effectiveness of online teaching higher in the case of teachers than in secondary school teachers? Obviously, parents were more involved in their children's learning activity, as evidenced by the $56.4 \%$ agreement quota with the statement "Since the beginning of the pandemic, I have been more concerned with my child's learning activity."

Furthermore, in terms of the evaluation activity, $56.9 \%$ of the respondents stated that they paid more attention to this aspect, as there is a stronger correlation for students and parents of primary school children.

Expectations regarding the transparency of the educational process are highlighted by the percentage of $93.1 \%$ of those who wish to receive reports and information on the educational processes and results during the semester.

The next set of questions aimed to quantify the attributes of social capital from the perspective of direct (students) and indirect (parents) adult beneficiaries of the educational process.
Although $95.3 \%$ of the respondents agree that school / university represents the support of the educational process in which all social stakeholders must be involved (pupils / students, parents, employers, local and central public administration), $65.8 \%$ are willing to get involved in volunteer activities, $60.4 \%$ in educational projects and only $35.6 \%$ express their will to participate in leadership structures on the level of the class / group or school / university, thus highlighting a rupture between ideal and real situation. From the perspective of distribution by age groups, the 35-45 age group is the one showing the highest availability of involvement, and from the viewpoint of income those who have a monthly family income between 5001 and 7500 lei. The strongest correlation between the attributes of social capital (involvement, collaboration, support) and the level of education is registered among the mothers of primary school pupils.

The last questions relevant to the topic of the paper highlight the perception on the education reform. The results exhibit a predominantly pessimistic approach and distrust in the possibility of achieving, in the next 4 years, a structural reform leading to a Romanian education system adapted to today's society.

Only $18.9 \%$ of the persons surveyed consider that a significant improvement of the education system in Romania is likely to take place, $16.4 \%$ say that the financing of education according to the law (allocation of $6 \%$ of GDP) is possible and unfortunately only $9.4 \%$ of respondents consider there will be a depolitisation of the educational system management. Surprisingly, more than $30.2 \%$ consider it possible to adapt school / university curricula to the requirements of the labour market. For this last item there is a significant Pearson correlation coefficient for the parents of middle school pupils, but in the case of parents of high school students, although Sig. takes the value 0.04 , the two variables are inversely correlated.

\section{Conclusions}

Educational policies are decided by the political class, which has no intellectual motivations or perspective on the educational profile of the society and its evolutionary dimension. The major problem facing national education is essentially the lack of prospect for curricular actors: pupils, teachers and the community. (Prodan \& Niţulescu, 2013)

The way in which the educational system participates in the development of social capital and in 
reverse, the way in which the stakeholders of the educational process are involved in the activity of school organisations has changed under the pressure of the health crisis generated by the SARS-COV-2 virus.

The transition from traditional on-site education to online education has generated a change in the schooladult relationship (parents, students) involved in the educational process, and the fact that almost $50 \%$ of them do not trust the effectiveness of the online teaching system, highlights a difficult transition to the digitalization of education.

The importance of using interactive teaching methods is highlighted in specialised studies (Niţulescu \& Constantin, 2019).

According to the results of research conducted in March-April 2020, on a sample of 201 people, the pandemic generated a forced activation of some attributes of social capital, such as parental involvement, and less on the voluntary side, educational projects, but in parallel it was found that the degree of confidence in achieving a substantial reform of the Romanian education system is extremely low.

The confusion of the authorities in taking effective measures to combat the effects of the pandemic, the difficulties in communication and the shortcomings of the education system as a whole were highlighted by the answers provided by the research participants.

These past two years have generated an even deeper polarization of the education system between urban and rural, highlighting on the one hand the system's malfunctions and an educational policy with many gaps. On the other hand, great difficulties in school organisations adaptation, from the perspective of the digital level of the teachers and of the technicalmaterial endowment.

The centralization of the results of the applied questionnaire highlighted a significant gap between the parents of primary school children and the parents of middle school pupils and high school students, the former being more willing to get involved in school activities, the interest decreasing with the increase of pupils' and students' age. Although it seems a natural trend, many studies show that parents' involvement would be useful for young adolescents, who are at increased risk of contagion with some dangerous habits (smoking, alcohol, drugs) at this stage of their life.
As an organization that constantly learns, adapting to changes in the internal and external environment, but also as an organization that represents a vehicle for change in the community, the school organization becomes a full learning organization.

The final conclusion of this article emphasizes the essential role of education in the development of social capital attributes at community and national level, but also the need to involve decision makers in designing a flexible education system, able to adapt and to involve all social stakeholders.

A constructivist approach to education that focuses on the safety needs and professional and personal development of students, cannot be implemented in the absence of involvement of their family and in the conditions of a precarious social capital in the community.

\section{Authors note:}

Mirela Minică is a University Associate professor, Ph.D. and is a Distance Learning Coordinator at the Faculty of Economics and Business Administration (University Center of Babeș-Bolyai University, Reșiţa, Romania). In 2001, she obtained a $\mathrm{PhD}$ in Macroeconomics, at University of Craiova. Her research interests are reflected in a series of studies and articles published in important national and international journals. Her teaching activity covers several areas, such as organizational culture, didactics in economic fields and management of educational organizations.

\section{References}

Bourdieu, P. (1981). Le capital social. Notes provisoires., Actes de la Recherche en Sciences Sociales 31, 2-3. Retrived from: www.persee.fr/doc/arss_03355322_1980_num_31_1_2069 (accessed 10.09.2021).

Bourdieu, P. (1985). Forms of Capital, in J. G. Richardson (ed.) Handbook of Theory and Research for the Sociology of Education, 251-258, New York: Greenwood Press.

Clifton, R.A., \& Roberts, L.W. (1993). Authority in classrooms. Scarborough, ON: Prentice-Hall Canada.

Coleman, J. (1988). Social Capital in the Creation of Human Capital, American Journal of Sociology 94, 95120 Retrived from: https://www.socialcapitalgateway.org/ (accessed 02.09.2021. 
Coleman, J. (1990). Foundations of Social Theory. Cambridge, MA: Harvard University Press.

Cristea S. (1998). Dicţionar de termeni pedagogici. (Dictionary of pedagogical terms) București: Editura Didactică şi Pedagogică.

Etcheverry, E., Clifton, RA \& Roberts L.W. (2001). Social Capital and Educational Attainment, The Alberta Journal of Educational Research Vol. XLVII, No. 1, 24-39.

Evans-Harvey, C. (1995). Creating a positive environment for learning in higher education. Canadian Society for the Study of Higher Education Professional File, 13, 18.

Fukuyama, F. (1995). Trust: The Social Virtues and the Creation of Prosperity. New York: Free Press.

Nițulescu, L., Constantin, A. (2019). Valorising the active methods in the study of pedagogical subjects. Journal Plus Education, Vol XXIII, Special Issue, 120-123.
Paxton, P. (2002). Social Capital and Democracy: An Interdependent Relationship, American Sociological Review 67, 254-77.

Păun, E. (1999). Şcoala abordare sociopedagogică (School socio-pedagogical approach), Iaşi: Editura Polirom.

Prodan, G., Niţulescu, L. (2013). Implication of social, economic and political organisations in contemporary education, Annals of Eftimie Murgu University of Resita, Issues II, Economic Sciences, 350-355.

Putnam, R. (2000). Bowling Alone: The Collapse and Revival of American Community. New York: Simon and Schuster.

Teachman, J.D., Paasch, K., \& Carver, K. (1997). Social capital and the generation of human capital. Social Forces, 75, 1343-1359.

Trișcă, G. (2013). Marketing experențial (Experiential marketing), Reșița: Editura Eftimie Murgu. 